\title{
The influence of brand equity on consumer responses toward Cho Gao dragon fruits brand
}

\author{
Tran Tien Khoa ${ }^{*}$, Nguyen Van Phuong ${ }^{1}$, Trinh Vu Anh Thi ${ }^{1}$, Nguyen Thi Minh Nguyet ${ }^{1}$, \\ Tran Van Dien ${ }^{1}$, Do Thi Sa Huynh ${ }^{1}$ \\ ${ }^{1}$ Center for Public Administration, International University \\ Vietnam National University - Ho Chi Minh City, Vietnam \\ *Corresponding author: ttkhoa@hcmiu.edu.vn
}

\begin{tabular}{|c|c|}
\hline ARTICLE INFO & ABSTRACT \\
\hline $\begin{array}{l}\text { Received: September } 16^{\text {th }}, 2019 \\
\text { Revised: November } 25^{\text {th }}, 2019 \\
\text { Accepted: April } 20^{\text {th }}, 2020\end{array}$ & $\begin{array}{l}\text { This thesis study wants to implement a model test for better } \\
\text { understandings of brand equity and consumer responses toward } \\
\text { Cho Gao Dragon Fruit brand. With the rapid growth of agriculture, } \\
\text { including domestic consumption and export of the dragon fruits, } \\
\text { it is crucial to differentiate the Cho Gao Dragon Fruits to other } \\
\text { competitors in both domestic and foreign markets. Using } \\
\text { Structural equation modeling (SEM) to analyze the data of } 274 \\
\text { questionnaires to investigate the effects of brand equity and its } \\
\text { dimensions on consumer responses. The results show that brand } \\
\text { equity dimensions such as brand awareness, brand association, } \\
\text { perceived quality are interrelated and those dimensions have a } \\
\text { direct and significant effect on brand equity, except brand } \\
\text { awareness. The results support the assumption that brand equity } \\
\text { has a positive relationship with consumer responses. The findings } \\
\text { shed light on the current issues of the market for dragon fruits, } \\
\text { which enables us to provide some suggestions for the Government } \\
\text { to facilitate farmers and traders in building brand names, } \\
\text { marketers for doing marketing activities, and students to know } \\
\text { about brand equity of agricultural product such as dragon fruits. }\end{array}$ \\
\hline
\end{tabular}

\section{Introduction}

Since 1993, Vietnam has the advantages of the dragon fruits' main supplier because of the favorable geographical conditions. According to Southern Fruit Research Institute (SOFRI) in 2013, 32 provinces, which covers more than 25,000 hectares of Dragon fruit, produce more than 460, 000 tones every year and directly contribute more than 150,000,000 USD per year. Since 2013, the Government and Tien Giang Agricultural Office, New Zealand Institute for Plant and Food Research (PRF), Southern Fruit Research Institute (SOFRI) have conducted many projects that aim to apply technologies enhancing the quality of dragon fruit grown and developing sustainable agriculture in Tien Giang. In addition, Tien Giang plans to increase this farming acreage to 4,500 hectares by 2015 along with speeding up trade promotion and expanding overseas outlets thank to the steady increases of trade every year and technology improvements. However, in recent years, many countries in the world like Thailand, Japan, and Taiwan have tried to grow Dragon fruits directed cause damage to Vietnamese farmers. That leads to the emergence of branding to compete in the diverse geographical market. 
In Vietnam, two types of Dragon fruits are already named: Binh Thuan Dragon fruits and Cho Gao Dragon fruits. Cho Gao Dragon fruits are famous for the red and thin cover compared to Binh Thuan Dragon fruits. Consumers can hardly differentiate between two kinds of brands. In fact, Cho Gao' farmers are expanding the capacity of growing Dragon fruit in recent years. Those events both are chances and challenges in competing in the domestic and foreign markets, so assessing brand equity to build up the successful strategies for strong brand-building and understandings of brand equity in different markets is needed, which will help our country protect and enhance this valued asset.

Moreover, brand equity can influence consumer behavior (Hoeffler \& Keller, 2003). Indeed, previous research shows that brand equity has a positive relationship with consumer responses (Cobb-Walgren, Ruble, \& Donthu, 1995). Aaker (1996) claimed a brand was the only way to remove oneself from commodity status price competition and in this case of commodity good (dragon fruits). Meanwhile, there is a shortage of empirical research exploring the relationships among brand equity dimensions and the impact of brand equity on the consumer responses in Vietnam. Hence, we conduct this study to bridge this gap, also we would like to contribute to the empirical literature of marketing for both marketers and students.

\section{Literature review}

\subsection{Brand equity}

Brand equity has been defined in many ways and many aspects since the 1980s. Simply, brand equity can be defined as the power of the brand in consumers' minds (Leone et al., 2006). In the research of Yoo and Donthu (2001), brand equity is defined as the incremental utility or value added to a product. Brand equity emerged as "a set of brand assets and liabilities linked to a brand, its name, and symbol" (Aaker \& Equity, 1991). These assets refer to brand awareness, perceived quality, brand associations, brand loyalty, and other proprietary assets (Buil, Martínez, \& De Chernatony, 2013). Keller, Parameswaran, and Jacob (2011) defined brand equity based on the perceptions of consumers, in terms of brand awareness, strength, preference, and brand associations that consumers hold in their memory.

In practice, brand equity is considered as the brand description or brand strength that is referred to as consumer-based brand equity which is different from the asset valuation definition (Wood, 2000). No matter how brand equity is defined, a brand must be valued by consumers, and the value of a brand reflects what consumers perceived (in five senses) and learned about the brand as a result of their experience over the time (Keller, Parameswaran, \& Jacob, 2011).

Following previous studies of Kim, Gon Kim, and An (2003); Pappu, Quester, and Cooksey (2006); Yoo, Donthu, and Lee (2000), this study applies the consumer-based definition of brand equity which is constructed by 4 dimensions: brand awareness, perceived quality, brand associations, and brand loyalty.

Scholars already proved that forming good brand equity can affect the future profit of an organization (Srivastava \& Shocker, 1991), the willingness to buy with premium prices (Keller, 1993), and the long-term competitive advantage (Bharadwaj, Varadarajan, \& Fahy, 1993).

\subsection{Geographical brand}

According to Docherty (2012), branding agricultural commodities: The development case for adding value through branding the geographical brands use the "geographical indicator" for 
branding tool that is considered as a representative of distinctiveness attributable to its origin in a defined geographical area. To some extent, a geographical indicator is defined as "identifying a good as originating in the territory of a Member, or a region or locality in that territory, where a given quality, reputation or another characteristic of the good is, essentially, attributable to its geographical origin".

Cho Gao, a rural district of Tien Giang Province in the Mekong Delta region of Vietnam, is the main supplier of Dragon fruits besides Binh Thuan Province, maintaining more than 3000 ha, supplying more than 50000 tones for export and domestic consumption in 2013 (Tien Giang Agricultural Office). Besides, Cho Gao is famous for Dragon fruits since the $20^{\text {th }}$ century, with features like heavy items, thin cover compared to other items of other suppliers.

\subsection{Brand equity dimensions}

The collective dimension of brand equity consists of four dimensions: brand awareness, brand loyalty perceived quality, and brand loyalty, as proposed by Aaker (1996); Aaker and Equity (1991); and Keller (1993). According to Strategic Brand Management of Keller et al. (2011), brand awareness consists of brand recognition and brand recall and many researchers reveal that consumer decision to purchase bases on the brand name, logo, packaging, and other visible characteristics of the product for brand recognition. Perceived quality and brand associations are also two key dimensions of brand equity (Buil, Martínez \& De Chernatony, 2013). Keller et al. (2011) claimed that strong brand association has a strong linkage to brand equity, in a simpler explanation, the brand association is every single feature that links the brand with consumers' memory (Aaker \& Equity, 1991). The judgments of the consumer on a product's overall excellence or superiority are the perceived quality (Zeithaml, 1988). The research of Yoo and Donthu (2001) defined brand loyalty as the tendency of a consumer to be loyal to a focal brand, which already presented in the research of Oliver, Rust, and Varki (1997) by purchase intention at first in the mind of consumers.

This research aims to investigate how consumer responses toward brand name Cho Gao Dragon fruits. The significant aspects of brand awareness are the ability of consumers to recognize and recall the performance of a brand. In the previous research of Pappu, Quester, and Cooksey (2006) claimed the causal relationships among brand awareness, brand associations, perceived quality, and brand loyalty. (Buil et al., 2013; Cobb-Walgren, Ruble, \& Donthu, 1995; Keller et al., 2011; Yoo et al., 2000) suggested a possible causal hierarchy among brand equity dimensions.

Brand awareness is the very first step of brand equity causal hierarchy (Aaker, 1996; Konecnik \& Gartner, 2007), that means whether consumers can recall or recognize the brand bases on the strengths of the brand perceived by the consumers. In contrast, perceived quality and brand association were influenced brand awareness according to Keller et al. (2011), he claimed that brand awareness of the liking brand links to different associations in memory. In other words, the brand association is valuable in the case consumers aware of the brand (Aaker \& Equity, 1991). Moreover, brand awareness affects the brand association strength and formation including the perceived quality (Buil et al., 2013; Keller, 1993). Therefore, we propose the following hypothesis:

H1: Brand awareness has a positive influence on perceived quality

H2: Brand awareness has a positive influence on the brand association 
Perceived quality and brand association was proposed to have an impact on customers' loyalty to the brand (Keller et al., 2011). With the support of other research, proved the positive relationship between perceived quality, brand association to brand loyalty (Keller et al., 2011). Therefore, we propose the following hypotheses:

\section{H3: Perceived quality has a positive influence on brand loyalty}

\section{H4: the brand association has a positive relationship on brand loyalty}

Brand association, perceived quality, brand loyalty were theorized positive effects on overall brand equity (Buil et al., 2013; Pappu et al., 2006). Previous research revealed that brand association can make firms differentiate themselves from others and improve brand equity (Hal Dean, 2004; Yoo et al., 2000). Higher perceived quality can offer the brands more competitive advantages among a bundle of brands in the market (Kim, Gon Kim, \& An, 2003; Yoo et al., 2000). Brand loyalty can be counted as the main major contributes to brand equity, loyal consumers can be another source of competitive advantage of the firm (Atilgan, Aksoy, \& Akinci, 2005; Yoo et al., 2000). Hence, we propose the following hypotheses:

\section{H5: Perceived quality has a positive influence on overall brand equity}

H6: Brand associations have a positive effect on overall brand equity

\section{H7: Brand loyalty has a positive influence on overall brand equity}

\subsection{Word of Mouth (WOM)}

Arndt (1967) claimed that WOM is the verbal communication between individuals about a service or a good via various channels such as email, telephone, mailing list, and other means of communication. In research of Bone (1995), WOM is created by conversations about product and services between who are not stake-holders of the company with a medium perceived of the producer. Higie, Feick, and Price (1987) also revealed in his research that conversation motivated by salient experience plays an important role in information diffusion.

Among the existing channel marketing for Dragon fruits in Vietnam, WOM is an easy and effective way to communicate with target consumers. Furthermore, in the research of Brown, Kozinets, and Sherry Jr (2003), and Katz, Lazarsfeld, and Roper (2017), WOM as a source of information has a significant influence on consumers' decisions than other marketing communication channels.

\subsection{Consumer responses}

In previous research, Buil et al. (2013) mentioned that consumer responses are the way consumers react toward a brand including four dimensions such as consumer willing to buy with price premium, the acceptance of consumer of brand extension, consumers' brand preference, and consumer purchase intention. This research supports the theory "overall brand equity has positive effects on consumer's response". Word of mouth, or "between-customer communication" has been defined as a potential driver of the customers' decision to buy products. WOM can be either positive or negative. The satisfied customer carries on purchasing the products and spreading the good news about these products; in contrast, in case of those who are dissatisfied, what remains in their minds are the disadvantages of the products and people are likely to tell other people about these things (Roster \& Richins, 2009). Considering how influential WOM would be to shape the perceptions of the customers, WOM should be another element of consumer response in this research. 
Buil et al. (2013) developed the research that counted the influence of brand equity on consumer responses in the UK and Spain in terms of four brand equity dimensions and empirically tested the relationship between overall brand equity toward consumers' responses. As a result, there is a strong relationship between brand equity and three dimensions of consumers' responses: willingness to buy price premium, brand preference, and purchase intention, the pessimistic result in brand extension. This research arm to test a specific brand that branding base on geographical, there is no reason for testing brand extension.

The willingness to buy a price premium is the number of money consumers who are willing to buy a product of a brand compared to other products of other brands with the same features or benefits (Keller et al., 2011). Brand equity influences consumer willingness to buy a product with a price premium, making price less of a consideration when purchasing a product (Keller \& Lehmann, 2003; Keller et al., 2011).

Brand preference was defined as the positive evaluations, preferences of a favorable brand compared to other brands (Keller et al., 2011), furthermore, research of Cobb-Walgren et al. (1995) showed that the higher brand equity the greater brand preferences, and higher tendencies to buying a product.

The relationship between brand preference and purchase intention was confirmed by the research of Buil et al. (2013) as well as in other research of Hellier, Geursen, Carr, and Rickard ( 2003), theorized by Ajzen and Fishbein (1977).

Several researchers have studied how WOM influences on the decision to purchase products among brands (Chevalier \& Mayzlin, 2006; Godes \& Mayzlin, 2009; Grewal, Cline, \& Davies, 2003; Herr, Kardes, \& Kim, 1991). There was remarkable literature discussing the impact of WOM on how consumers make their decision (Chen, Wang, \& Xie, 2011; Gupta \& Harris, 2010; Herr, Feick, \& Price, 1991), especially for new products (Peres, Muller, \& Mahajan, 2010).

Therefore, we propose the following hypotheses: premiums

H8: Overall brand equity has positive influences on consumers' willingness to buy price

H9: Overall brand equity has a positive influence on consumers' brand preferences

H10: Overall brand equity has a positive influence on consumer's purchase intention

H11: Overall brand equity has a positive influence on consumer's WOM (Word of Mouth)

H12: Brand reference has a positive influence on consumer's purchase intention

H13: Word of mouth (WOM) has a positive influence on consumer purchase intention

In the study of Roberts, Morrison, Chandrashekaran, and Gordon (2004), he argued that WOM is encouraged by the preference for brands. According to (Hutter, Hautz, Dennhardt, \& Füller, 2013), there was a significant influence of brand awareness on word of mouth. Therefore, we propose the following hypothesis:

H14: Brand awareness has a positive influence on WOM (Word of Mouth)

\section{Methodology}

In this study, we applied the back-translation procedure of Brislin, Lonner, and Thorndike (1973) to ensure the English and Vietnamese versions of questionnaires have equivalent meanings. We converted the English questionnaire into Vietnamese and then translated it back into English. 
This approach allows us to eliminate the potential discrepancies by comparing the second English version to the original one to ensure the consistency in meaning. All measurement items were evaluated on a 5-point Likert scale ranging from 1 (strongly disagree) to 5 (strongly agree).

\subsection{Measurement scales}

All the measurement scales were constructed based on previous literature. The list of all 36 items used to measure 9 latent variables in the study is presented in the following table:

Table 1

Measurement scales

\begin{tabular}{|c|c|}
\hline Construct & Measurement \\
\hline $\begin{array}{l}\text { Brand awareness } \\
\text { (Yoo et al., 2000) }\end{array}$ & $\begin{array}{l}\text { AW 1. I am aware of brand X } \\
\text { AW2. When I think of X, brand X is one of the brands that come to my mind } \\
\text { AW3. X is a brand of Dragon fruits I am very familiar with } \\
\text { AW4. I Know brand X look like } \\
\text { AW5. I can recognize brand X among other competing brands of Dragon } \\
\text { fruits }\end{array}$ \\
\hline $\begin{array}{l}\text { Perceive quality } \\
\text { (Pappu et al., } \\
\text { 2006) }\end{array}$ & $\begin{array}{l}\text { PQ1. Brand X offers very good quality products } \\
\text { PQ2. Brand X offers products of consistent quality } \\
\text { PQ3. Brand X offers very reliable products } \\
\text { PQ4. Brand X offers the product with excellent feature }\end{array}$ \\
\hline $\begin{array}{l}\text { Brand associations } \\
\text { (Aaker, 1996; } \\
\text { Pappu et al., 2006) }\end{array}$ & $\begin{array}{l}\text { AS1. Brand X is a good value for money } \\
\text { AS2. Among Dragon fruits brands, I consider brand X a good buy } \\
\text { AS3. Considering what I pay for a brand X, I would get much more than my } \\
\text { money's worth } \\
\text { AS4. I trust the place which makes brand X } \\
\text { AS5. I like the place which makes brand X } \\
\text { AS6. The place which makes brand X is credibility }\end{array}$ \\
\hline $\begin{array}{l}\text { Brand Loyalty } \\
\text { (Yoo et al., 2000) }\end{array}$ & $\begin{array}{l}\text { LO1. I consider myself to be loyal to brand } X \\
\text { LO2. Brand X would be my first choice when considering buying Dragon fruits } \\
\text { LO3. I will not buy other brands of Dragon Fruit if brand X is available in store }\end{array}$ \\
\hline $\begin{array}{l}\text { Overall brand } \\
\text { equity } \\
\text { (Yoo et al., 2000) }\end{array}$ & $\begin{array}{l}\text { OBE1. Even if another Dragon fruits brand has the same features as brand } \\
\mathrm{X}, \mathrm{I} \text { still choose } \mathrm{X} \\
\text { OBE2. If there was another brand of Dragon fruits as good as X, I still choose } \mathrm{X} \\
\text { OBE3. If another brand of Dragon fruits is not different from X in any way, } \\
\text { I still choose X }\end{array}$ \\
\hline $\begin{array}{l}\text { Consumer } \\
\text { willingness to pay } \\
\text { a price premium } \\
\text { Netemeyer et al. }\end{array}$ & $\begin{array}{l}\text { PR1. The price of brand X would have to go up quite a bit before I would } \\
\text { not consider buying it } \\
\text { PR2. I am willing to pay a higher price for brand X (Dragon fruits) than for } \\
\text { other brands of Dragon fruits }\end{array}$ \\
\hline
\end{tabular}




\begin{tabular}{|l|l|}
\hline \multicolumn{1}{|c|}{ Construct } & \multicolumn{1}{c|}{ Measurement } \\
\hline (2004) & $\begin{array}{l}\text { PR3. I am willing to pay a lot more for brand X (Cho Gao Dragon fruits) } \\
\text { than for other brands of Dragon fruits }\end{array}$ \\
\hline $\begin{array}{l}\text { Brand reference } \\
\text { Sirgy et al. (1997) }\end{array}$ & $\begin{array}{l}\text { PRE1. I like brand X better than other brands of Dragon fruits } \\
\text { PRE2. I would use brand X more than other brands of Dragon fruits } \\
\text { PRE3. Among brands of Dragon fruits, brand X is my preferred brand when } \\
\text { I choose to buy }\end{array}$ \\
\hline $\begin{array}{l}\text { Purchase intention } \\
\text { Valenzuela (2006) }\end{array}$ & $\begin{array}{l}\text { PI1. I would buy brand X (Cho Gao Dragon fruits) because I know it well } \\
\text { PI2. I would seriously consider buying brand X (Cho Gao Dragon fruits) } \\
\text { PI3. It is very likely that I would buy brand X (Cho Gao Dragon fruits) } \\
\text { because I know it well } \\
\text { PI4. Next time if I have demand for Dragon fruits, I would buy brand X }\end{array}$ \\
\hline $\begin{array}{l}\text { Word-of-mouth } \\
\text { Goyette, Ricard, } \\
\text { Bergeron, and } \\
\text { Marticotte (2010) }\end{array}$ & $\begin{array}{l}\text { WOM1. I mostly say positive things to others. } \\
\text { WOM2. I am proud to say to others that I am Brand X (Cho Gao Dragon } \\
\text { WOM3. I strongly recommend people buy products of Brand X (Cho Gao } \\
\text { Dragon fruits) } \\
\text { WOM4. I spoke of Brand X (Cho Gao Dragon fruits) much more frequently } \\
\text { than about any other } \\
\text { WOM5. I would give a recommendation about Brand X for acquaintances } \\
\text { when they need Dragon Fruit }\end{array}$ \\
Brand X is Cho Gao Dragon fruits \\
\hline Note
\end{tabular}

Source: The research's data analysis

\subsection{Data collection}

\subsubsection{Research design}

The survey questionnaires are distributed to gain the perceptions of consumers about brand equity dimensions, overall brand equity, and consumer responses toward Cho Gao Dragon fruits brand. The data was collected through surveys at several locations in Ho Chi Minh City, Tien Giang province, and Long An province.

The questionnaire was constructed with two parts: demographic information and survey questions. The respondents were asked to complete the Vietnamese version of the questionnaire with a clear explanation. We always welcomed additional questions from respondents for further explanations of ambiguous meanings (if any) or misunderstandings of some conceptual words. Respondents are free to stop the survey at any time and have the right to refuse to answer any specific questions if they did not have experience or knowledge of the surveyed questions.

Eventually, out of the total of 350 distributed questionnaires, there are 274 valid observations. The sample size of this study meets the acceptable standard, representing the population. 
The demographic profile of the sample in Table 2 reveals a relative balance between male and female respondents, respectively $52.8 \%$ and $47.2 \%$. The table also provides information about the ratio of age among respondents. Overall, the age group ranging from 18 to 40 takes a vast majority with $64.4 \%$. Following is the $40-65$ age group accounting for $23.7 \%$. The less-than- 18 and greater-than-65 age groups contribute a minority of $9.5 \%$ and $2.4 \%$ respectively.

Additionally, this table shows how often the respondents consumed Dragon fruits during a week during peak season. Nearly half of the sample admitted that they eat Dragon fruits less than 2 times a week in the peak season accounting for $49.3 \%$. 87 people said that they consume Dragon fruits $2-7$ times per week (31.8\%). In this research, $12.4 \%$ of the total respondents claimed that they know about Dragon fruits but never eat. Finally, contributing to the lowest percentage is the number of people who consume over 7 times a week, making up $6.6 \%$.

Table 2

Demographic information

\begin{tabular}{lcc}
\hline Characteristics & Number $(\mathbf{N}=\mathbf{2 7 4})$ & Percentage \\
\hline Gender & & \\
Male & 145 & $52.9 \%$ \\
Female & 129 & $47.2 \%$ \\
\hline Age & & \\
Under 18 & 26 & $9.5 \%$ \\
From 18 to 40 & 176 & $64.2 \%$ \\
From 40 to 65 & 65 & $23.7 \%$ \\
Over 65 & 7 & $2.6 \%$ \\
\hline Frequency of Consumption & & \\
Less than 2 times per week & 135 & $49.3 \%$ \\
2-7 times per week & 87 & $31.8 \%$ \\
Over 7 times per week & 18 & $6.5 \%$ \\
Know but never eat & 34 & $12.4 \%$ \\
\hline
\end{tabular}

Source: The research's data analysis

\subsubsection{Data analysis technique}

This study made use of SPSS 22 and AMOS 22 for the statistical analysis of the collected data. First, we took the exploratory factor analysis (EFA) and confirmatory factor analysis (CFA) to preliminarily test the dimensionality, convergent, and discriminant validity of the data. Second, the underlying causal effects among the 9 variables and their respective items in the theoretical model were discovered thanks to the application of structural equation modeling (SEM) approach.

\section{Results}

\subsection{Reliability and construct validity}

According to Hair, Anderson, Tatham, and Black (1998), factor loading and the KaiserMeyer-Olkin (KMO) which is greater than 0.5 can be considered as practically significant.

After eliminating 11 items that are below the standard requirements, 3 factors are deleted, including Brand loyalty, Price premium, Brand preference. The remaining factors together with the item factor loadings and overall alpha indices are demonstrated in the table below: 
Table 3

Data description and reliability analysis

\begin{tabular}{|c|c|c|c|c|c|}
\hline Construct & $\begin{array}{c}\text { Items } \\
\text { (variable coding) }\end{array}$ & Mean & SD & EFA & Alpha \\
\hline \multirow{5}{*}{ Brand awareness (AW) } & & & & & 0.858 \\
\hline & AW1 & 4.2226 & .90869 & 0.925 & \\
\hline & AW2 & 4.0073 & .97962 & 0.838 & \\
\hline & AW3 & 4.0438 & .99720 & 0.849 & \\
\hline & AW4 & 3.7664 & 1.09118 & 0.731 & \\
\hline \multirow{3}{*}{ Perceived quality (PQ) } & & & & & 0.860 \\
\hline & PQ2 & 3.6606 & .94817 & 0.852 & \\
\hline & PQ3 & 3.8248 & .93682 & 0.508 & \\
\hline \multirow{5}{*}{ Brand associations (AS) } & & & & & 0.895 \\
\hline & $\mathrm{AS} 2$ & 3.7883 & .94486 & 0.408 & \\
\hline & AS4 & 3.9672 & .97722 & 0.869 & \\
\hline & AS5 & 3.9416 & .98164 & 0.924 & \\
\hline & AS6 & 3.9453 & 1.00581 & 0.892 & \\
\hline \multirow{4}{*}{ Overall brand equity (OBE) } & & & & & 0.793 \\
\hline & OBE1 & 3.5547 & 1.10224 & 0.794 & \\
\hline & OBE2 & 3.4708 & 1.04174 & 0.869 & \\
\hline & OBE3 & 3.3905 & 1.03636 & 0.880 & \\
\hline \multirow{5}{*}{ Purchase intention (PI) } & & & & & 0.865 \\
\hline & PI1 & 3.9343 & .97368 & 0.607 & \\
\hline & PI2 & 3.6241 & 1.03116 & 0.618 & \\
\hline & PI3 & 3.4964 & 1.08350 & 0.617 & \\
\hline & PI4 & 3.7591 & 1.00930 & 0.591 & \\
\hline \multirow{6}{*}{ Words of mouth (WOM) } & & & & & 0.902 \\
\hline & WOM1 & 3.9088 & 1.04604 & 0.716 & \\
\hline & WOM2 & 3.7737 & 1.08599 & 0.734 & \\
\hline & WOM3 & 3.8832 & .94977 & 0.905 & \\
\hline & WOM4 & 3.9307 & 1.00490 & 1.060 & \\
\hline & WOM5 & 4.0401 & .91098 & 0.832 & \\
\hline
\end{tabular}

Notes: SD: Standard deviation. 5-point Likert-type scales, with 1 representing strongly disagree to 5 representing strongly agree. Loading items were extracted from the maximum Likelihood with rotation method of Promax Source: Data analysis result of the research

\subsection{Confirmatory Factor Analysis (CFA)}

In this stage of the research progress, Confirmatory Factor Analysis is used to test the relationships among 6 latent variables - Brand Awareness (AW), Perceived quality (PQ), Brand Association (AS), Overall brand equity (OBE), Word of Mouth (WOM), and Purchase Intention 
(PI). In specific, the next step is conducting the CFA test with remaining items that were grouped in 6 factors (use items which were eliminated from Reliability and EFA). Furthermore, to process the Confirmatory Factor Analysis for each variable, the AMOS 22 software is applied. In short, CFA was conducted to testify whether the measurement model fits with the data from the survey.

Table 4

Model fit indices in CFA

\begin{tabular}{lcc}
\hline Model fit indices & Recommended acceptable level & Indices value \\
\hline CMIN/df & 1 to 3 & 2.187 \\
RMSEA & $<0.08$ & 0.06 \\
CFI & $>=0.90$ & 0.938 \\
TLI & $>=0.90$ & 0.926 \\
GFI & $>0.90$ & 0.872 \\
\hline
\end{tabular}

Source: Data analysis result of the research

\subsection{Convergent validity and discriminant validity}

To examine the convergent validity of a measurement scale, two indicators were considered: the average variance extracted (AVE) and the composite reliability (CR). The minimum value of the AVE should be at least 0.5 , and that of the CR should be greater than the 0.6 cut-off point to ensure the construct convergent validity (Fornell \& Larcker, 1981). Also, based on the simulation results of Fornell and Larcker's research (1981), a value of AVE between 0.4 and 0.5 may be considered acceptable when the value of the CR is higher than 0.6, in all the measurement models. Furthermore, Malhotra (2010) also argued that the value of the AVE was too strict, and reliability could be established through the $\mathrm{CR}$ alone.

After conducting the CFA, the convergent validity met these criteria. Table 5 showed that all estimates and the AVEs of all factors were higher than 0.5 and the composite reliability values of all factors were higher than 0.7 , all of which meet the requirement. In sum, the convergent validities of all constructs were confirmed, and the reliability for all constructs and items of this model completely satisfied the criteria.

\section{Table 5}

The overall reliability of the construct

\begin{tabular}{ccc} 
& CR & AVE \\
\hline WOM & 0.902 & 0.649 \\
AW & 0.822 & 0.607 \\
AS & 0.859 & 0.604 \\
PQ & 0.796 & 0.665 \\
OBE & 0.795 & 0.565 \\
PI & 0.854 & 0.596 \\
\hline
\end{tabular}

Source: Data analysis result of the research

The results of analyzing SEM was illustrated in Table 6. Overall, the goodness of fit statistics was acceptable, and the estimated coefficients were standardized. 
Table 6

Structural model results

\begin{tabular}{|l|c|l|}
\hline \multicolumn{1}{|c|}{ Effect from } & Hypothesis & \multicolumn{1}{c|}{ Estimates } \\
\hline Brand awareness $\rightarrow$ Perceived quality. & $\mathrm{H} 1$ & $0.653^{* * *}$ \\
\hline Brand awareness $\rightarrow$ Brand association. & $\mathrm{H} 2$ & $0.812^{* * *}$ \\
\hline Perceived quality $\rightarrow$ Brand loyalty & $\mathrm{H} 3$ & $\mathrm{~ns}$ \\
\hline Brand association $\rightarrow$ Brand loyalty & $\mathrm{H} 4$ & $\mathrm{~ns}$ \\
\hline Perceived quality $\rightarrow$ Overall brand equity. & $\mathrm{H} 5$ & $0.470^{* *}$ \\
\hline Brand associations $\rightarrow$ Overall brand equity & $\mathrm{H} 6$ & $0.565^{*}$ \\
\hline Brand loyalty $\rightarrow$ Overall brand equity. & $\mathrm{H} 7$ & $\mathrm{~ns}$ \\
\hline Overall brand equity $\rightarrow$ Willingness to buy price premium. & $\mathrm{H} 8$ & $\mathrm{~ns}$ \\
\hline Overall brand equity $\rightarrow$ Brand preference & $\mathrm{H} 9$ & $\mathrm{~ns}$ \\
\hline Overall brand equity $\rightarrow$ Purchase intension. & $\mathrm{H} 10$ & $0.143^{*}$ \\
\hline Overall brand equity $\rightarrow$ WOM (Word of Mouth) & $\mathrm{H} 11$ & $0.120^{*}$ \\
\hline Brand reference $\rightarrow$ Purchase intention. & $\mathrm{H} 12$ & $\mathrm{~ns}$ \\
\hline Word of mouth (WOM) $\rightarrow$ Purchase intention. & $\mathrm{H} 13$ & $1.095^{* * *}$ \\
\hline Brand awareness $\rightarrow$ WOM (Word of Mouth) & $\mathrm{H} 14$ & $0.671^{* * *}$ \\
\hline Goodness of fit statistics CMIN/DF=2.288; CFI=0.933; GFI=0.866; TLI=0.919; RMSEA=0.69 \\
\hline
\end{tabular}

Notes: Standardized structural coefficients; ${ }^{* *} \mathrm{p}<0.001 ;{ }^{*} \mathrm{p}<0.005 ;{ }^{*} \mathrm{p}<0.05$; ns: non-significant

Source: Data analysis result of the research

\section{Discussion}

In line with previous studies of (Buil et al., 2013; Keller, 1993), brand awareness is significant in shaping the customers' perceptions of the product quality (in this case, the quality of dragon fruits) and associations with the brand, both of which in turn enhance the overall brand equity ( Hal Dean, 2004; Kim et al., 2003; Yoo et al., 2000) (support H1, H2, H5, H6). In contrast to the study of (Keller et al., 2011), perceived quality and brand associations are shown to have no relationships with brand loyalty which consequently shows no connection to overall brand equity (reject H3, H4, H7). Inconsistent with previous studies of (Keller \& Lehmann, 2003; Keller et al., 2011), overall brand equity is insignificant in relation to willingness to buy at a price premium and brand preference (reject H8, H9). However, overall brand equity is statistically proved to significantly stimulate WOM and customers' purchase intention (support H10, H11). While preference for the brand is insignificant to customers' intention to buy, WOM is evidenced to be a strong driver of the purchasing decision (reject H12, support H13). In line with the study of (Hutter et al., 2013), WOM can be strongly enhanced by the high awareness of customers of the brand (support H14). 


\section{Implications}

The research has much useful information on brand building for the Cho Gao Dragon fruits brand. This research use sample (non-students) and involve a different type of brand association (Yoo \& Donthu, 2001), especially makes adaption organization associations to Geographical indicator (Cho Gao). As a result, people who perceived well with Cho Gao brand have a positive relationship to overall brand equity. Besides, some people in the research admit that they choose Cho Gao Dragon fruits because of its shape (beautiful, and thin cover) rather than its taste like Mrs. Hoa-officer of a book shop in Tien Giang, Mr. Tu- worker of Royal company in Tien Giang. Those are noticed points for Marketers to emphasize on in the content of marketing activities for Cho Gao Dragon fruits brand.

Results provide empirical proof that brand equity has a significant predictor of positive consumer response. From this point, brand equity should be strengthened to benefit farmers and traders. WOM still an effective way to tell the good side about the product and communicate with the consumer, the producer should strengthen this channel to draw the attention of consumers and push them to purchase the product.

Cho Gao Dragon fruits brand is in the developing stage, this research built the base knowledge for readers about brand equity and consumer responses toward Cho Gao Dragon fruits in 2014, that will benefit the students' knowledge about brand equity, an indicator for Marketer to build brand equity for this kind of product. Furthermore, based on the result of this research the Government can use this research to guide the farmers, the traders the way to improve brand equity that generates future income for those individuals and organizations.

Further research should be compared to the brand equity of Cho Gao Dragon fruits and other brands of Dragon Fruit, extend the geography of the sample across the country. The findings benefit for domestic consumption not for exporting, future research should link the domestic and oversea consumer responses toward the brand. The results built the base on consumers' perception, further research should be drawn a correlation between the perception measure and the behavioral outcome.

\section{Conclusion}

In the brand equity literature, there is little research in Vietnam concentrates on brand equity and consumer respond of agricultural product especially Dragon fruits (potential products). The existent researches of Dragon Fruit are mainly focused on the Supply Chain of this product or how to standardize the quality of the product, whilst, this research is not only investigating the relationships between dimensions of brand equity toward brand equity but also the consumer's respond toward brand equity. Besides, this study promotes Word of Mouth as an effective channel to marketing in Dragon fruits brand.

The research results show that a casual order in the creation of brand equity exists somehow such as awareness contribute directly to perceived quality and brand association. Brand association and perceived quality can cause a positive relationship on overall brand equity. However, Brand awareness, in theory, can have a direct influence on overall brand equity, in this research this dimension doesn't have a significant impact on overall brand equity that revealed the same result in the research of Chu (2014) and Maio Mackay (2001). In the research of Chu (2014), COO (country of origin) has a significant relationship with the overall brand equity of cosmetics in 
Vietnam but not brand awareness. The result also corroborates the positive influence of brand equity on consumer response. Meanwhile, most papers assume that brand equity has a positive relationship with consumers' response, this paper empirically proves that overall brand equity direct influence on Word of mouth and purchase intention. Purchase intention is influenced by Word of mouth as well. Brand Preference and willingness to buy price premium don't contribute significant influence on this study. In summary, the result of data analysis and finding gives the research study many useful and practical results especially for agriculture products in Vietnam.

\section{References}

Aaker, D. A. (1996). Measuring brand equity across products and markets. California Management Review, 38(3), 102-120. doi:10.2307/41165845

Aaker, D. A., \& Equity, M. B. (1991). Capitalizing on the value of a brand name. New York, 28(1), 35-37.

Ajzen, I., \& Fishbein, M. (1977). Attitude-behavior relations: A theoretical analysis and review of empirical research. Psychological Bulletin, 84(5), 888-918. doi:10.1037/00332909.84.5.888

Arndt, J. (1967). Word of mouth advertising: A review of the literature. New York, NY: Advertising Research Foundation.

Atilgan, E., Aksoy, Ş., \& Akinci, S. (2005). Determinants of the brand equity: A verification approach in the beverage industry in Turkey. Marketing Intelligence \& Planning, 23(3), 237-248.

Bharadwaj, S. G., Varadarajan, P. R., \& Fahy, J. (1993). Sustainable competitive advantage in service industries: A conceptual model and research propositions. Journal of Marketing, 57(4), 83-99. doi:10.2307/1252221

Bone, P. F. (1995). Word-of-mouth effects on short-term and long-term product judgments. Journal of Business Research, 32(3), 213-223.

Brislin, R. W., Lonner, W. J., \& Thorndike, R. M. (1973). Cross-cultural research methods. New York, NY: John Wiley and Sons.

Brown, S., Kozinets, R. V., \& Sherry, J. F., Jr. (2003). Teaching old brands new tricks: Retro branding and the revival of brand meaning. Journal of Marketing, 67(3), 19-33. doi:10.1509/jmkg.67.3.19.18657

Buil, I., Martínez, E., \& De Chernatony, L. (2013). The influence of brand equity on consumer responses. Journal of Consumer Marketing, 30(1), 62-74.

Chen, Y., Wang, Q., \& Xie, J. (2011). Online social interactions: A natural experiment on word of mouth versus observational learning. Journal of Marketing Research, 48(2), 238-254. doi:10.1509/jmkr.48.2.238

Chevalier, J. A., \& Mayzlin, D. (2006). The effect of word of mouth on sales: Online book reviews. Journal of Marketing Research, 43(3), 345-354. doi:10.1509/jmkr.43.3.345

Chu, N. T. (2014). Understanding the relationship between country of origin image and brand equity - Case of cosmetic brands in Ho Chi Minh City. International Proceedings of Economics Development and Research, 78, 12-16. 
Cobb-Walgren, C. J., Ruble, C. A., \& Donthu, N. (1995). Brand equity, brand preference, and purchase intent. Journal of Advertising, 24(3), 25-40. doi:10.1080/00913367.1995.10673481

Docherty, C. (2012). Branding agricultural commodities: The development case for adding value through branding. Retrieved August 10, 2019, from International Institute for Environment and Development website: pubs.iied.org/16509IIED.html?

Erdem, T., Swait, J., \& Valenzuela, A. (2006). Brands as signals: A cross-country validation study. Journal of Marketing, 70(1), 34-49.

Fornell, C., \& Larcker, D. F. (1981). Evaluating structural equation models with unobservable variables and measurements error. Journal of Marketing Research, 18(4), 39-50. doi: $10.2307 / 3151312$

Godes, D., \& Mayzlin, D. (2009). Firm-created word-of-mouth communication: Evidence from a field test. Marketing Science, 28(4), 721-739.

Goyette, I., Ricard, L., Bergeron, J., \& Marticotte, F. (2010). e-WOM scale: Word-Of-Mouth measurement scale for e-services context. Canadian Journal of Administrative Sciences/Revue Canadienne Des Sciences de l'Administration, 27(1), 5-23. doi:10.1002/CJAS.129

Grewal, R., Cline, T. W., \& Davies, A. (2003). Early-entrant advantage, word-of-mouth communication, brand similarity, and the consumer decision-making process. Journal of Consumer Psychology, 13(3), 187-197.

Gupta, P., \& Harris, J. (2010). How e-WOM recommendations influence product consideration and quality of choice: A motivation to process information perspective. Journal of Business Research, 63(9/10), 1041-1049.

Hair, J. F., Anderson, R. E., Tatham, R. L., \& Black, W. C. (1998). Multivariate data analysis with readings (5th ed.). Upper Saddle River, NJ: Prentice-Hill.

Hal Dean, D. (2004). Evaluating potential brand associations through conjoint analysis and market simulation. Journal of Product \& Brand Management, 13(7), 506-513. doi:10.1108/10610420410568444

Hellier, P. K., Geursen, G. M., Carr, R. A., \& Rickard, J. A. (2003). Customer repurchase intention: A general structural equation model. European Journal of Marketing, 37(11/12), 1762-1800. doi:10.1108/03090560310495456

Herr, P. M., Kardes, F. R., \& Kim, J. (1991). Effects of word-of-mouth and product-attribute information on persuasion: An accessibility-diagnosticity perspective. Journal of Consumer Research, 17(4), 454-462. doi:10.1086/208570

Higie, R. A., Feick, L. F., \& Price, L. L. (1987). Types and amount of word-of-mouth communications about retailers. Journal of Retailing, 63(3), 260-278.

Hoeffler, S., \& Keller, K. L. (2003). The marketing advantages of strong brands. Brand Management, 10, 421-445. doi:10.1057/palgrave.bm.2540139

Hutter, K., Hautz, J., Dennhardt, S., \& Füller, J. (2013). The impact of user interactions in social media on brand awareness and purchase intention: The case of MINI on Facebook. Journal of Product \& Brand Management, 22(5/6), 342-351. 
Katz, E., Lazarsfeld, P. F., \& Roper, E. (2017). Personal influence: The part played by people in the flow of mass communications. London, UK: Routledge.

Keller, K. L. (1993). Conceptualizing, measuring, and managing customer-based brand equity. Journal of Marketing, 57(1), 1-22. doi:10.2307/1252054

Keller, K. L., \& Lehmann, D. R. (2003). How do brands create value? Marketing Management, 12(3), 26-31.

Keller, K. L., Parameswaran, M. G., \& Jacob, I. (2011). Strategic brand management: Building, measuring, and managing brand equity. New Delhi, India: Pearson Education India.

Kim, H., Gon Kim, W., \& An, J. A. (2003). The effect of consumer-based brand equity on firms' financial performance. Journal of Consumer Marketing, 20(4), 335-351. doi:10.1108/07363760310483694

Konecnik, M., \& Gartner, W. C. (2007). Customer-based brand equity for a destination. Annals of Tourism Research, 34(2), 400-421. doi:10.1016/j.annals.2006.10.005

Leone, R. P., Rao, V. R., Keller, K. L., Luo, A. M., McAlister, L., \& Srivastava, R. (2006). Linking brand equity to customer equity. Journal of Service Research, 9(2), 125-138. doi:10.1177/1094670506293563

Maio Mackay, M. (2001). Evaluation of brand equity measures: Further empirical results. Journal of Product \& Brand Management, 10(1), 38-51.

Malhotra, N. K. (2010). Marketing research: An applied orientation. London, UK: Pearson.

Netemeyer, R. G., Krishnan, B., Pullig, C., Wang, G., Yagci, M., Dean, D., ... Wirth, F. (2004). Developing and validating measures of facets of customer-based brand equity. Journal of Business Research, 57(2), 209-224. doi:10.1016/S0148-2963(01)00303-4

Oliver, R. L., Rust, R. T., \& Varki, S. (1997). Customer delight: Foundations, findings, and managerial insight. Journal of Retailing, 73(3), 311-336. doi:10.1016/S0022-4359(97)90021-X

Pappu, R., Quester, P. G., \& Cooksey, R. W. (2006). Consumer-based brand equity and countryof-origin relationships: Some empirical evidence. European Journal of Marketing, 40(5/6), 696-717. doi:10.1108/03090560610657903

Roberts, J., Morrison, P., Chandrashekaran, M., \& Gordon, A. (2004). Measuring sources and outcomes of brand equity. Paper presented at the Australian and New Zealand Marketing Conference.

Roster, C. A., \& Richins, M. L. (2009). Ambivalence and attitudes in consumer replacement decisions. Journal of Consumer Psychology, 19(1), 48-61. doi:10.1016/j.jcps.2008.12.008

Sirgy, M. J., Grewal, D., Mangleburg, T. F., Park, J., Chon, K. S., Claiborne, C. B.,... Berkman, H. (1997). Assessing the predictive validity of two methods of measuring self-image congruence. Journal of the Academy of Marketing Science, 25(3), 229-241.

Srivastava, R. K., \& Shocker, A. D. (1991). Brand equity: A perspective on its meaning and measurement. Cambridge, MA: Marketing Science Institute. 
Wood, L. (2000). Brands and brand equity: Definition and management. Management Decision, 38(9), 662-669. doi:10.1108/00251740010379100

Yoo, B., \& Donthu, N. (2001). Developing and validating a multidimensional consumer-based brand equity scale. Journal of Business Research, 52(1), 1-14. doi:10.1016/S01482963(99)00098-3

Yoo, B., Donthu, N., \& Lee, S. (2000). An examination of selected marketing mix elements and brand equity. Journal of the Academy of Marketing Science, 28(2), 195-211. doi:10.1177/0092070300282002

Zeithaml, V. A. (1988). Consumer perceptions of price, quality, and value: A means-end model and synthesis of evidence. Journal of Marketing, 52(3), 2-22. doi:10.2307/1251446 


\section{APPENDIX}

The Influence of brand equity on consumer responses toward Cho Gao Dragon Fruits Brand

Part 1.

\begin{tabular}{|c|c|c|c|}
\hline \multicolumn{2}{|r|}{ Sex } & \multicolumn{2}{|r|}{ Ages } \\
\hline & Male & $\square$ & $<18$ \\
\hline$\square$ & Female & $\square$ & $18-25$ \\
\hline & Others & $\square$ & $20-22$ \\
\hline & & $\square$ & $>22$ \\
\hline
\end{tabular}

How often do you consume Dragon fruit?

$\square$ Over 7 times/week

$\square$ 2-7 times per week

$\square$ Less than 2 times per week

$\square$ Never eat

\section{Part 2.}

Please give your opinions Cho Gao Blue Dragon brand? Please indicate how much you agree with the following statements:
1.Totally disagree
2. Disagree
3. Neutral
4. Agree
5. Totally agree

\begin{tabular}{|l|l|l|l|l|l|l|}
\hline \multicolumn{2}{|l|}{} & 1 & 3 & 3 & 4 & 5 \\
\hline \multicolumn{2}{|l|}{ The awareness of consumer toward Cho Gao Blue Dragon brand } \\
\hline I am aware of brand Cho Gao Blue Dragon brand & $\square$ & $\square$ & $\square$ & $\square$ & $\square$ \\
\hline $\begin{array}{l}\text { When I think of Dragon Fruit, Cho Gao Blue Dragon brand is } \\
\text { the one that comes to mind. }\end{array}$ & $\square$ & $\square$ & $\square$ & $\square$ \\
\hline $\begin{array}{l}\text { Cho Gao Blue Dragon brand is a brand of Dragon fruit I am } \\
\text { very familiar with. }\end{array}$ & $\square$ & $\square$ & $\square$ & $\square$ & $\square$ \\
\hline I know what Cho Gao Blue Dragon brand look like & $\square$ & $\square$ & $\square$ & $\square$ & $\square$ \\
\hline $\begin{array}{l}\text { I can recognize brand X among other competing brand of } \\
\text { Dragon Fruit }\end{array}$ & $\square$ & $\square$ & $\square$ & $\square$ & $\square$ \\
\hline The perceive quality of consumer toward Cho Gao Blue Dragon brand & & $\square$ & $\square$ & $\square$ & $\square$ \\
\hline Cho Gao Blue Dragon brand offers very good quality products & $\square$ & $\square$ & $\square$ & $\square$ & $\square$ \\
\hline $\begin{array}{l}\text { Cho Gao Blue Dragon brand offers products of consistent } \\
\text { quality }\end{array}$ & $\square$ & $\square$ & $\square$ & $\square$ & $\square$ \\
\hline Cho Gao Blue Dragon brand offers very reliable products & $\square$ & $\square$ & $\square$ & $\square$ & $\square$ \\
\hline $\begin{array}{l}\text { Cho Gao Blue Dragon brand offers products with excellent } \\
\text { features }\end{array}$ & $\square$ & $\square$ & $\square$ & $\square$ & $\square$ \\
\hline
\end{tabular}




\begin{tabular}{|c|c|c|c|c|c|}
\hline & 1 & 3 & 3 & 4 & 5 \\
\hline \multicolumn{6}{|c|}{ The perceive value of consumer toward Cho Gao Blue Dragon brand } \\
\hline Cho Gao Blue Dragon brand is good value for the money & $\square$ & $\square$ & $\square$ & $\square$ & $\square$ \\
\hline $\begin{array}{l}\text { Within Dragon Fruit brand I consider Cho Gao Blue Dragon } \\
\text { brand a good buy }\end{array}$ & $\square$ & $\square$ & $\square$ & $\square$ & $\square$ \\
\hline $\begin{array}{l}\text { Considering what I would pay for Cho Gao Blue Dragon brand, } \\
\text { I would get much more than my money's worth }\end{array}$ & $\square$ & $\square$ & $\square$ & $\square$ & $\square$ \\
\hline \multicolumn{6}{|l|}{ The perceive of consumer toward organizational association } \\
\hline I trust the district which makes Cho Gao Blue Dragon & $\square$ & $\square$ & $\square$ & $\square$ & $\square$ \\
\hline I like the district which makes Cho Gao Blue Dragon & $\square$ & $\square$ & $\square$ & $\square$ & $\square$ \\
\hline The district which makes Cho Gao Blue Dragon is credibility & $\square$ & $\square$ & $\square$ & $\square$ & $\square$ \\
\hline \multicolumn{6}{|l|}{ Consumers' brand loyalty toward Cho Gao Blue Dragon brand } \\
\hline I consider myself to be loyal to Cho Gao Blue Dragon brand & $\square$ & $\square$ & $\square$ & $\square$ & $\square$ \\
\hline $\begin{array}{l}\text { Cho Gao Blue Dragon brand would be my first choice when } \\
\text { considering Dragon Fruit }\end{array}$ & $\square$ & $\square$ & $\square$ & $\square$ & $\square$ \\
\hline $\begin{array}{l}\text { I will not buy other brands of Dragon Fruit if Cho Gao Blue } \\
\text { Dragon brand available on store }\end{array}$ & $\square$ & $\square$ & $\square$ & $\square$ & $\square$ \\
\hline \multicolumn{6}{|l|}{ The overall brand equity toward Cho Gao Blue Dragon brand } \\
\hline $\begin{array}{l}\text { Even if another Dragon fruit brand has the same features as Cho } \\
\text { Gao Blue Dragon brand, I still choose Cho Gao Blue Dragon }\end{array}$ & $\square$ & $\square$ & $\square$ & $\square$ & $\square$ \\
\hline $\begin{array}{l}\text { If there was another brand of Dragon Fruit as good as Cho Gao } \\
\text { Blue Dragon, I still choose Cho Gao Blue Dragon }\end{array}$ & $\square$ & $\square$ & $\square$ & $\square$ & $\square$ \\
\hline $\begin{array}{l}\text { If there was another brand of Dragon fruit is not different from } \\
\text { Cho Gao Blue Dragon brand in anyway }\end{array}$ & $\square$ & $\square$ & $\square$ & $\square$ & $\square$ \\
\hline \multicolumn{6}{|l|}{ Consumers' willingness to buy a price premium } \\
\hline $\begin{array}{l}\text { The price of Cho Gao Blue Dragon brand would have to go up } \\
\text { quite a bit before I still buy it }\end{array}$ & $\square$ & $\square$ & $\square$ & $\square$ & $\square$ \\
\hline $\begin{array}{l}\text { I am willing to pay a higher price for Cho Gao Blue Dragon } \\
\text { brand than other brand of Dragon fruit }\end{array}$ & $\square$ & $\square$ & $\square$ & $\square$ & $\square$ \\
\hline $\begin{array}{l}\text { I am willing to buy a lot more Cho Gao Blue Dragon brand than } \\
\text { other brand of Dragon fruit }\end{array}$ & $\square$ & $\square$ & $\square$ & $\square$ & $\square$ \\
\hline \multicolumn{6}{|c|}{ Brand preference of consumers toward Cho Gao Blue Dragon brand } \\
\hline $\begin{array}{l}\text { I like Cho Gao Blue Dragon brand better than other brand of } \\
\text { Dragon fruit }\end{array}$ & $\square$ & $\square$ & $\square$ & $\square$ & $\square$ \\
\hline $\begin{array}{l}\text { I would consume Cho Gao Blue Dragon more than other brand } \\
\text { of Dragon fruit }\end{array}$ & $\square$ & $\square$ & $\square$ & $\square$ & $\square$ \\
\hline $\begin{array}{l}\text { In Dragon fruit brand Cho Gao Blue Dragon is my preference } \\
\text { brand when I choose to buy Dragon Fruit }\end{array}$ & $\square$ & $\square$ & $\square$ & $\square$ & $\square$ \\
\hline
\end{tabular}




\begin{tabular}{|c|c|c|c|c|c|}
\hline & 1 & 3 & 3 & 4 & 5 \\
\hline \multicolumn{6}{|c|}{ Consumers' purchase intention toward Cho Gao Blue Dragon brand } \\
\hline I would buy Cho Gao Blue Dragon because I know it well & $\square$ & $\square$ & $\square$ & $\square$ & $\square$ \\
\hline I would seriously consider buy Cho Gao Blue Dragon brand & $\square$ & $\square$ & $\square$ & $\square$ & $\square$ \\
\hline $\begin{array}{l}\text { It very likely that I would buy Cho Gao Blue Dragon brand, } \\
\text { whenever I buy fruits }\end{array}$ & $\square$ & $\square$ & $\square$ & $\square$ & $\square$ \\
\hline \multicolumn{6}{|l|}{$\begin{array}{l}\text { Next time when I need Blue Dragon, I definitely buy Cho Gao } \\
\text { Blue Dragon product }\end{array}$} \\
\hline \multicolumn{6}{|l|}{ Word of Mouth } \\
\hline I mostly say positive things to others. & $\square$ & $\square$ & $\square$ & $\square$ & $\square$ \\
\hline $\begin{array}{l}\text { I am proud to say other that I am Chợ Gạo Blue Dragon’s } \\
\text { customer. }\end{array}$ & $\square$ & $\square$ & $\square$ & $\square$ & $\square$ \\
\hline $\begin{array}{l}\text { I strongly recommend people buy products of Chợ Gạo Blue } \\
\text { Dragon }\end{array}$ & $\square$ & $\square$ & $\square$ & $\square$ & $\square$ \\
\hline $\begin{array}{l}\text { I spoke of Chợ Gạo Blue Dragon much more frequently than } \\
\text { about any other Dragon Fruit Brand }\end{array}$ & $\square$ & $\square$ & $\square$ & $\square$ & $\square$ \\
\hline $\begin{array}{l}\text { I would give recommendation about Cho Gao Blue Dragon for } \\
\text { acquaintances when they need Dragon Fruit }\end{array}$ & $\square$ & $\square$ & $\square$ & $\square$ & $\square$ \\
\hline
\end{tabular}

